\title{
IBUPROFEN IMPROVES SURVIVAL AND NEUROLOGIC OUTCOME AFTER RESUSCITATION FROM CARDIAC ARREST*
}

JOHN E. KUHN, CYNTHIA N. STEIMLE, GERALD B. ZELENOCK and LOUIS G. D'ALECY

Departments of Physiology and Surgery, The University of Michigan Medical School, Ann Arbor, MI 48104 (U.S.A.)

(Received April 30th, 1986)

(Revision received August 30th, 1986)

(Accepted September 5th, 1986)

\section{SUMMARY}

Post-ischemic inflammatory changes in the central nervous system (CNS) following cardiac arrest and resuscitation are potentially responsible for ultimate survival and much of the neurologic damage, producing greater morbidity and mortality in successfully resuscitated patients. This study was undertaken to assess the non-steroidal anti-inflammatory agent, ibuprofen, in a controlled and monitored experimental model of canine cardiac arrest and resuscitation. With the investigator blinded as to the intervention, eight of 21 dogs were randomly assigned to receive ibuprofen as an i.v. bolus $(10 \mathrm{mg} / \mathrm{kg})$ and a $6-\mathrm{h}$ i.v. infusion $(5 \mathrm{mg} / \mathrm{kg}$ per $\mathrm{h})$. The other $13 \mathrm{dogs}$ received an equivalent volume of $0.9 \% \mathrm{NaCl}$ to serve as controls. No statistically significant differences between the two groups were detected in any pre-arrest variables. All 21 dogs were successfully resuscitated. At 24 h, dogs receiving ibuprofen exhibited $100 \%$ survival, while control dogs exhibited only $54 \%$ survival $(P=0.03)$. The majority of deaths for the control group occurred within the first $6 \mathrm{~h}$. Neurologic deficit scores were assigned at 1, 2, 6 and $24 \mathrm{~h}$ after resuscitation. A general trend occurred such that dogs treated with ibuprofen improved over time, while the control dogs remained severely impaired. A significant difference in neurologic deficit score was detected at $6 \mathrm{~h}(P=0.01)$. At $24 \mathrm{~h}$ the ibuprofen group exhibited minimal neurologic deficit $(5.9 \pm 3.2)$, and the control group exhibited significantly more severe neurologic impairment $(52.2 \pm 13.0, P=0.01)$. These results suggest that ibuprofen may be helpful in the pharmacologic management of cardiac arrest as a means of increasing survival and decreasing neurologic impairment.

*This study was made possible by gift from the Upjohn Company, Kalamazoo, MI 49001 , U.S.A. 
Key words: Ibuprofen - Cerebral resuscitation - Cardiac arrest

\section{INTRODUCTION}

Despite standardization of techniques and pharmacologic protocols for resuscitation, cardiac arrest remains a leading cause of morbidity and mortality in industrialized nations. Most series report survivals of less than 20\% and neurologic morbidity in survivors is profound. In a recent 10-year retrospective study from Seattle (Longstreth et al., 1983a and b), the most successful experience reported to date, an unprecedented $50 \%$ of all cardiac arrest patients were successfully resuscitated, and yet only $41 \%$ of those resuscitated regained consciousness without neurologic impairment. In this favorable series a completely successful result following resuscitation from cardiac arrest thus only occurred $20 \%$ of the time.

In attempts to improve this outcome, a number of therapeutic interventions have been tested experimentally in both the laboratory and the clinical setting. These include pharmacologic agents such as barbiturates, steroidal and non-steroidal anti-inflammatory drugs, calcium channel blockers, oxygen radical scavengers, various diuretics and osmotics, and a plethora of agents with hemodynamic effects. Ibuprofen, a non-steroidal anti-inflammatory agent has not yet been tested in the setting of cardiac arrest and resuscitation. However, ibuprofen has been shown to reduce myocardial infarct size in dogs by up to $49 \%$ (Jugdutt et al., 1980), presumably due to an inhibition of inflammatory mediators (Flynn et al., 1984). Because the neural damage following circulatory arrest may be caused at least in part by similar inflammatory mechanisms, we decided to investigate the role that ibuprofen may play in improving the neurologic outcome and survival in the setting of cardiac arrest and resuscitation.

\section{METHODS}

\section{Preparation and experimental procedure}

Twenty-one fed mongrel dogs $(15.9-28.6 \mathrm{~kg})$ were pre-medicated with morphine sulfate, $(1.5 \mathrm{mg} / \mathrm{kg}$ i.m. $)$. Anesthesia was induced with $5 \%$ halothane via mask and demand ventilation. Once anesthetized, the dogs were intubated and maintained on 1-2\% halothane (Compact-75, Foregger, Westmont, IL) via controlled ventilation (Anesthesia Ventilator, Bennettt, Westmont, IL). Neuromuscular blocking agents were not used. Carbon dioxide concentration in respiratory gas was continuously monitored with an infrared analyzer (LB-2, Beckman, SensorMedics Co, Anaheim, CA) and end expiratory $\mathrm{CO}_{2}$ was maintained between $4-5 \%$. An esophageal temperature probe was inserted to the level of the heart. Body temperature was 
monitored and maintained at $39^{\circ} \mathrm{C}$ with a heating pad and proportional controller. An indwelling urethral catheter was placed to allow estimation of urine production. Two venous catheters were inserted. One catheter was inserted through the femoral vein for fluid infusion. A second catheter, which was used for resuscitation drug administration and central venous pressure monitoring, was advanced through the external jugular vein to the superior vena cava so that the tip lay near the right atrial opening. A catheter was advanced from the femoral artery to the common iliac artery to monitor pulsatile blood pressure.

A left thoracotomy in the fifth intercostal space provided access to the heart, and the pericardium was opened to facilitate direct cardiac compression. Subcutaneous electrocardiographic electrodes were placed to monitor Lead II ECG. This ECG, along with mean and pulsatile arterial pressure, heart rate, and expiratory carbon dioxide tension were recorded on an oscillograph (Gould-Brush 200, Cleveland, $\mathrm{OH}$ ). When the preparation was complete, the dogs were disconnected from the anesthesia machine and connected to a room air ventilator (Harvard 607, South Natick, MA) to reduce and standardize the level of anesthesia at which fibrillation would be induced. The heart was fibrillated after corneal reflexes had consistently returned by delivering a $60 \mathrm{~Hz}, 2 \mathrm{~ms}$ square wave stimulus to the epicardial surface of the left ventrical. Circulatory arrest was confirmed by evaluation of the ECG tracing, arterial pressure pulse, and by direct observation.

After 6 min of circulatory arrest resuscitation began with direct cardiac massage, which maintained arterial blood pressure above $75 \mathrm{mmHg}$. In all dogs drugs were rapidly injected into the central venous catheter in the following sequence and doses: an epinephrine injection $(20 \mu \mathrm{g} / \mathrm{kg})$ and infusion ( $4 \mu \mathrm{g} / \mathrm{kg}$ per min via femoral venous catheter), an injection of $\mathrm{NaHCO}_{3}(2 \mathrm{meq} / \mathrm{kg})$, an injection of lidocaine $(1 \mathrm{mg} / \mathrm{kg})$, and an injection of $\mathrm{CaCl}_{2}(25 \mathrm{mg} / \mathrm{kg})$. At this point a bolus injection of either ibuprofen $(10 \mathrm{mg} /$ $\mathrm{kg}$ ) or an equivalent volume of $0.9 \% \mathrm{NaCl}$ was administered. Dogs receiving an ibuprofen bolus $(N=8)$ also received an infusion of ibuprofen $(5 \mathrm{mg} / \mathrm{kg}$ per h) for $6 \mathrm{~h}$, and dogs receiving a bolus of saline $(N=13)$ received an equivalent volume of $0.9 \% \mathrm{NaCl}$ infused at the same rate (approx. $9.0 \mathrm{ml} / \mathrm{h}$ ). The dogs were biock randomized in groups of three and four (treatment and control respectively) which should have given sample sizes of 9 and 12, however, one animal was misassigned resulting in the final sample size of 8 treated and 13 control animals. The investigators were blinded to the treatment throughout the study. All dogs received 5\% dextrose in lactated Ringer's solution at $120 \mathrm{ml} / \mathrm{h}$ for the first $6 \mathrm{~h}$ and at $65 \mathrm{ml} / \mathrm{h}$ for the next $18 \mathrm{~h}$ (total volume less than $2 \mathrm{l}$ in $24 \mathrm{~h}$ ).

As soon as the initial sequence of drugs was administered (approx. $1 \mathrm{~min}$ ) defibrillation was attempted by delivering a charge of 40-80J, (PhysioControl, Lifepak-3, Worthington, $\mathrm{OH}$ ), with $31 \mathrm{sq} \mathrm{cm}$ paddles placed on the ventricular surface. Additional injections or charges were administered when indicated by arterial blood pressure and ECG tracings. Epinephrine infusion 
was adjusted to maintain mean arterial pressure between 100 and $125 \mathrm{mmHg}$, and was stopped when the dog was capable of maintaining a mean pressure greater than $100 \mathrm{mmHg}$, or at $6 \mathrm{~h}$ post-arrest.

The chest was closed and evacuated when a stable rhythm and pressure developed. The dogs were ventilated until spontaneous ventilation returned, and were extubated upon the return of the gag reflex. The dogs were then placed in a cage where blood pressure, heart rate, ECG and central venous pressure were continuously monitored for $24 \mathrm{~h}$ using a standard dog jacket and swivel (Alice King Chatham Medical Arts, Los Angeles, CA). An antibiotic (Polyflex, $6.6 \mathrm{mg} / \mathrm{Kg}$ i.m.) was given to all dogs, and morphine sulfate (1.5 mg/Kg i.m.) was used as needed when the dogs showed signs of pain or discomfort.

At $1,2,6$ and $24 \mathrm{~h}$ post-arrest, a neurologic score (D'Alecy, 1986) described in Table I was assigned. All scoring was done by two or more blinded investigators, who referred to written descriptions of each test condition. Postmortem examinations of the heart, lungs and wound site were conducted to identify hemorrhage, heartworm infestation, catheter placements or any iatrogenic problem relating to the thoracotomy or resuscitation that may have contributed to the death of any of the dogs. The entire experimental procedure conformed to the guidelines set by the American Physiological Society and was approved by The University of Michigan Unit for Laboratory Animal Medicine's Vertebrate Animal Use Committee (D001068D).

\section{Data analysis}

Statistical analysis was performed with the aid of the Michigan Interactive Data Analysis System (MIDAS) on an Amdahl 5860 computer. Both the parametric Student's $t$-test and non-parametric Kruskel-Wallis tests were used to evaluate neurologic scores. Fisher's exact test was used for survival data. All average data are expressed as mean \pm one standard error of the mean (S.E.M.). The sample size $(N)$ for all experiments is the number of animals. Exact $P$-values are given except when $P>0.15$ where it is reported as nonsignificant (NS).

\section{RESULTS}

For the two groups, the average values of the pre-arrest variables of body weight, operative time (anesthesia induction to fibrillation), mean arterial pressure, heart rate, and end-expiratory carbon dioxide were not statistically different (Table II).

All 21 dogs were successfully resuscitated. Figure 1 illulstrates the time of death for each dog and the survival for each group to $24 \mathrm{~h}$. All dogs receiving ibuprofen survived $(N=8)$, while the group that did not receive ibuprofen (the control group, $N=13$ ) showed significant mortality in the first $6 \mathrm{~h}$. At $24 \mathrm{~h}$, the control group exhibited only $54 \%$ survival which is significantly 
TABLE I

\section{NEUROLOGIC DEFICIT SCORE}

Neurologic deficit score was previously published (D'Alecy, 1986) and addresses five major areas and increases with the severity of the damage.

\begin{tabular}{|c|c|c|c|}
\hline Consciousness & & Respiration & \\
\hline Normal & (0) & Normal & (0) \\
\hline Conscious continually & (3) & Extubated/abnormal & (6) \\
\hline Conscious intermittently & (6) & Intubated/spontaneous & (12) \\
\hline Stuporous & (12) & On ventilator & (18) \\
\hline Light coma & (15) & Subtotal & 118 \\
\hline Deep coma & (18) & & \\
\hline Subtotal & $/ 18$ & & \\
\hline & & $\begin{array}{l}\text { Cranial nerves } \\
\quad(\text { Strong }=0, \text { Weak }=1, \text { Absent }=2)\end{array}$ & \\
\hline Motor function & & Corneal reflex & (2) \\
\hline Normal & (0) & Pupillary light reflex & (2) \\
\hline Minimal ataxia & (2) & Facial sensation & (2) \\
\hline Ataxia & (4) & Gag reflex & (2) \\
\hline Stands spontaneously & (6) & Jaw reflex & (2) \\
\hline Sits spontaneously & (10) & Olfactory reflex & (2) \\
\hline Sits if posed & (12) & Swallowing reflex & (2) \\
\hline Spont. dorsal recumbency & (14) & Subtotal & $/ 16$ \\
\hline Posed dorsal recumbency & (16) & & \\
\hline Spontaneous purposeful & (18) & & \\
\hline Provoked purposeful & $(20)$ & Spinal nerves & \\
\hline Reflex, spastic, or & & $($ Normal $=0$, Spastic $=2$, Faccid $=4$ & \\
\hline convulsive mvmt only & $(24)$ & Limb tone: front & (4) \\
\hline No movement & $(28)$ & Limb tone: hind & (4) \\
\hline Subtotal & $/ 28$ & Normel-0 Wol & \\
\hline & & $\begin{array}{l}(\text { Normal }=0, \text { Weak }=2, \text { Absent }=4) \\
\text { Pain reflex: front } \\
\text { Pain reflex: hind } \\
\text { Knee jerk reflex }\end{array}$ & $\begin{array}{l}(4) \\
(4) \\
(4)\end{array}$ \\
\hline & & Subtotal & 120 \\
\hline & & TOTAL $=$ & $/ 100$ \\
\hline
\end{tabular}

lower than the ibuprofen group's $100 \%$ survival (Fisher's exact, $P=0.03$ ).

No differences between groups were detected for the resuscitation time (the time from the beginning of resuscitation to the establishment of stable cardiac rhythm and a mean arterial blood pressure greater than $75 \mathrm{mmHg}$ without external compression), the number of defibrillating shocks, the time the animals had to be ventilated, the time until the animals were extubated, amount of epinephrine administered (as both the injection and infusion), the $\mathrm{NaHCO}_{3}$, lidocaine, calcium chloride, or morphine used (Table III).

Figure 2 depicts the mean arterial pressure during pre-arrest period and from the end of the $6 \cdot \mathrm{h}$ support period to $24 \mathrm{~h}$. There were no significant 
TABLE II

\section{PRE-ARREST VARIABLES}

Average pre-arrest variables for the ibuprofen-treated and the vehicle control group of dogs given as the mean \pm one standard error of the mean. $P$-values reflect Student's $t$-tests for all variables.

\begin{tabular}{lccc}
\hline Variable & $\begin{array}{l}6 \mathrm{~h} \text { ibuprofen } \\
\text { infusion }\end{array}$ & Vehicle control & $P$ \\
\hline $\begin{array}{l}\text { Sample size }(N) \\
\text { Body weight } \\
\quad(\mathrm{kg})\end{array}$ & 8 & 13 & \\
$\begin{array}{l}\text { Operative time } \\
\quad(\min )\end{array}$ & $19.5 \pm 0.7$ & $20.9 \pm 0.9$ & $\mathrm{NS}$ \\
$\begin{array}{l}\text { Mean Art Pressure } \\
\quad(\text { mmHg) }\end{array}$ & $83 \pm 9$ & $93 \pm 6$ & NS \\
$\begin{array}{l}\text { Heart rate } \\
\quad \text { (beats/min) }\end{array}$ & $138 \pm 17$ & $135 \pm 6$ & NS \\
$\begin{array}{c}\text { End expired CO, } \\
(\%)\end{array}$ & $89 \pm 10$ & $104 \pm 8$ & NS \\
\hline
\end{tabular}

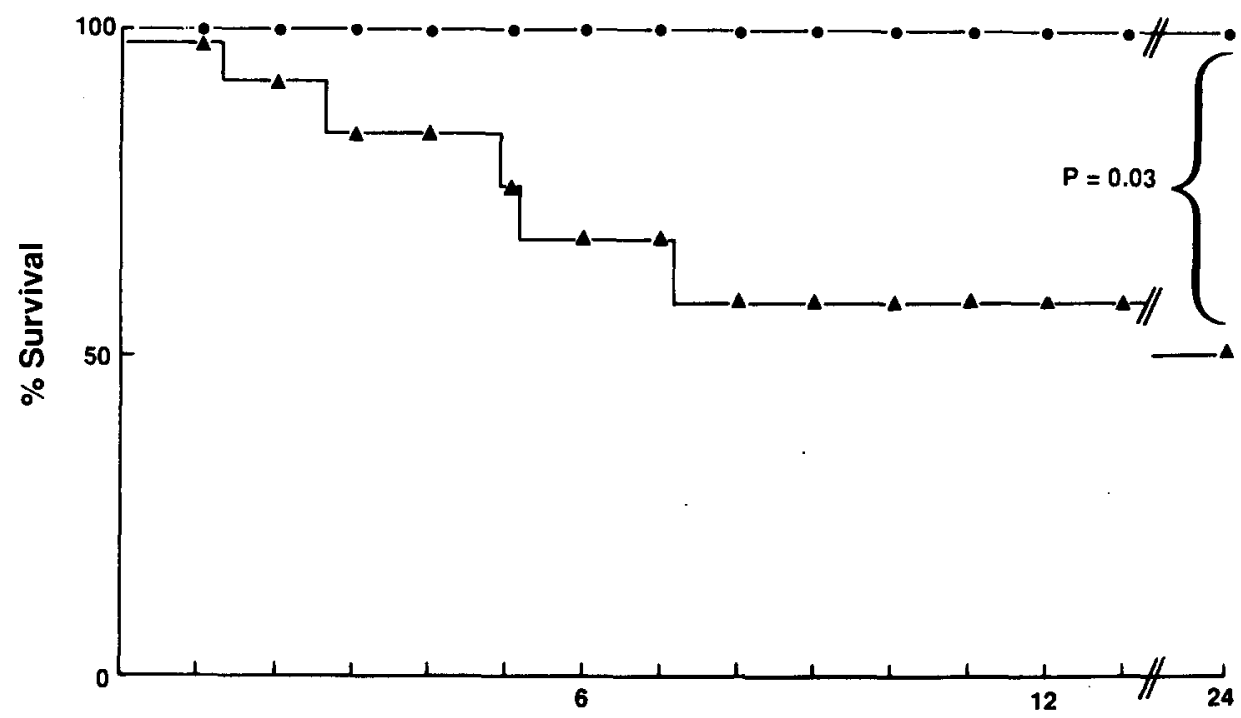

Hours

Fig. 1. Percent survival for the ibuprofen-treated group and the vehicle control group plotted against time in hours. The sample size for the ibuprofen treated group was eight, and the initial sample size for the vehicle control group was $13 . \bullet-\circ$, ibuprofen in. fusion; $\triangle \longrightarrow$, vehicle control. 


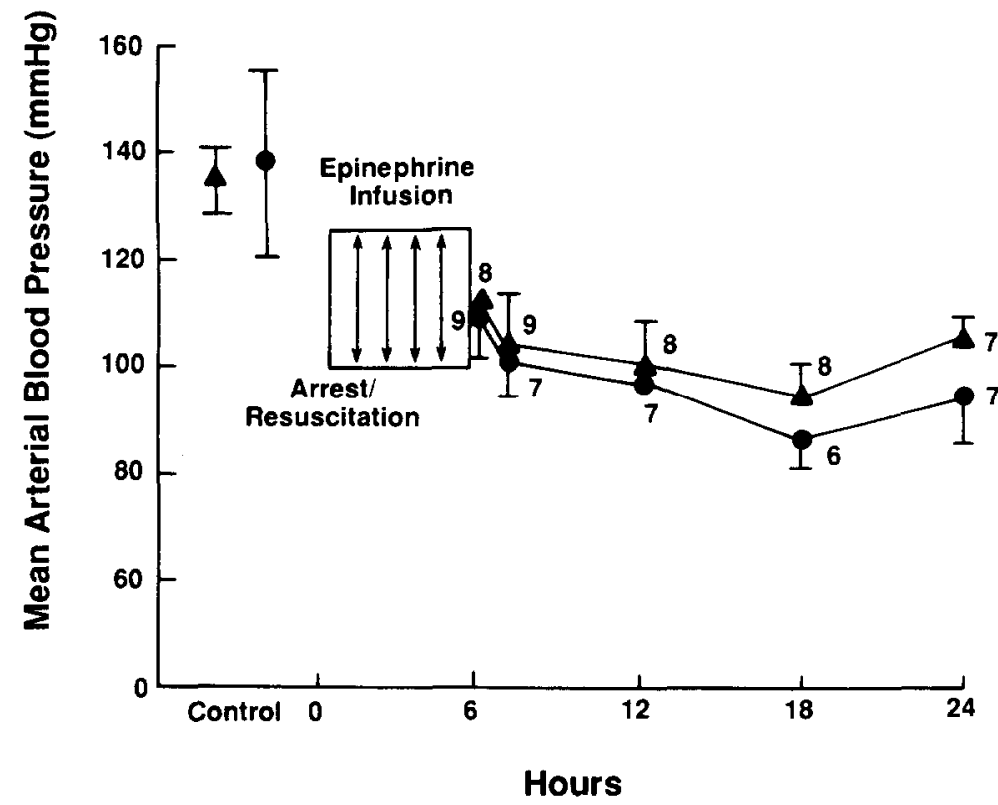

Fig. 2. The symbols at the far left indicate one standard error of the mean about the pre-arrest values of mean arterial pressure for the two groups. The box with arrows indicates the range in which pressure was controlled for the $6 \mathrm{~h}$ following arrest and resuscitation. Sample size is next to each data point. Values were taken just after $6 \mathrm{~h}$ when pressure stabilized and at $7,12,18$ and $24 \mathrm{~h}$ post-resuscitation. At no time were the two groups significantly different, •, 6-h ibuprofen infusion; 4 , vehicle control.

differences between groups in blood pressure for any time throughout the experiment. Furthermore, heart rates measured at 6 and $24 \mathrm{~h}$, and endexpired $\mathrm{CO}_{2}$ both on the ventilator and when the animals were taken off the ventilator were not significantly different (Table IV).

Statistical analysis of the neurologic deficit score (Table I) of the groups at one, two, six, and 24 hours is illustrated in Fig. 3. If a dead animal is scored as 100 both parametric (Student's $t$, top row) and non-parametric (Kruskal-Wallis, bottom row) analysis of the deficit is possible. The inclusion of a dead dog in a neurologic deficit score may be misleading, especially if the cause of death could be attributed to non-neurologic causes. We included such subjects in our neurologic scoring for the following reasons: (1) postmortem examination did not reveal any iatrogenic problems related to the thoracotomy or resuscitation that could account for the death of any animal; (2) none of the dogs died from ventricular fibrillation and most dogs $(N=19)$ had regained spontaneous ventilation with hyperpnea within less than $1 \mathrm{~h}$ (all dogs within $3 \mathrm{~h}$ ); (3) cardiopulmonary depression appeared to be secondary to progressive neurologic damage as evidenced by stable ECG rhythms; and (4) all the animals that died had fixed and dilated pupils, little 
TABLE III

\section{RESUSCITATION PROCEDURE VARIABLES}

Average values of the resuscitation procedure variables for the ibuprofen-treated and the vehicle control groups of dogs. Values are presented as the mean \pm one standard error of the mean. The $P$-values are from Student's $t$-test in all cases.

\begin{tabular}{|c|c|c|c|}
\hline Variable name & $\begin{array}{l}6 \mathrm{~h} \text { ibuprofen } \\
\text { infusion }\end{array}$ & $\begin{array}{l}\text { Vehicle } \\
\text { control }\end{array}$ & $P$ \\
\hline Sample size $(N)$ & 8 & 13 & \\
\hline $\begin{array}{l}\text { Resuscitation time } \\
\text { (min) }\end{array}$ & & & \\
\hline $\begin{array}{l}\text { (min) } \\
\text { No. of shocks } \\
\text { Ventilation time }\end{array}$ & $\begin{array}{ll}7.0 \pm & 1.8 \\
3 & \pm 1\end{array}$ & $\begin{array}{cll}10.4 & \pm & 2.9 \\
4 & \pm & 1\end{array}$ & NS \\
\hline $\begin{array}{l}(\min ) \\
\text { Extubation time }\end{array}$ & $23 \pm 2$ & $51 \pm 17^{a}$ & NS \\
\hline $\begin{array}{l}(\min ) \\
\text { Epi injection dose }\end{array}$ & $161 \pm 58$ & $157 \pm 34^{b}$ & NS \\
\hline $\begin{array}{l}\text { Epi injection dose } \\
\quad(\mathrm{mg} / \mathrm{kg}) \\
\text { Epi infusion time }\end{array}$ & $57.5 \pm 2.6$ & $66.2 \pm 4.1$ & NS \\
\hline $\begin{array}{l}(\min ) \\
\text { Total } \mathrm{NaHCO}_{3} \text { dose }\end{array}$ & $33 \pm 4$ & $83 \pm 31$ & NS \\
\hline $\begin{array}{l}(\mathrm{meq} / \mathrm{kg}) \\
\text { Total lidocaine dose }\end{array}$ & $2.3 \pm 0.3$ & $2.6 \pm 0.4$ & NS \\
\hline $\begin{array}{l}(\mathrm{mg} / \mathrm{kg}) \\
\text { Calcium chloride }\end{array}$ & $6.1 \pm 1$ & $6.2 \pm 1$ & NS \\
\hline $\begin{array}{c}(\mathrm{mg} / \mathrm{kg}) \\
\text { Morphine dose }\end{array}$ & $31 \pm 6$ & $44 \pm 1$ & NS \\
\hline $\begin{array}{l}\text { Morphine dose } \\
(\mathrm{mg} / \mathrm{kg})\end{array}$ & $2.1 \pm 0.7$ & $1.1 \pm 0.4^{\mathrm{a}}$ & NS \\
\hline
\end{tabular}

a,b These values were obtained with a smaller sample size than indicated due to death and other causes: $\mathrm{a}=(N-1), \mathrm{b}=(N-2)$.

or no somatosensory response, and death was often preceded by convulsivelike activity, and limb extension with arching of the back.

For neurologic deficit, a general trend developed such that the neurologic deficit decreases over time for the ibubrofen-treated animals, while the control group remains significantly impaired (Fig. 3). Statistically significant differences $(P<0.05)$ between the two groups developed as early as $6 \mathrm{~h}$ after the resuscitation. The ibuprofen-treated animals displayed moderate neurologic impairment $(30.1 \pm 2.0)$, while the control animals displayed significantly (Student's $t, P=0.016)$ more severe impairment (58.7 \pm 8.2 ). At $24 \mathrm{~h}$, the dogs receiving ibuprofen displayed a mean neurologic deficit score of $5.9 \pm 3.2$, while the vehicle control group had more severe neurologic deficit, displaying a score of $52.2 \pm 13.0$ (Student's $t, P=0.013$ ). Even if the dead control dogs are not included in the neurologic scoring, the dogs receiving ibuprofen averaged about half the neurologic deficit of the surviving control dogs (5.9 \pm 3.2 as compared to $11.3 \pm 5.2)$ however, this difference was not statistically significant $(P=0.38)$. 


\section{TABLE IV}

\section{POST-RESUSCITATION PHYSIOLOGIC MEASUREMENTS}

Average values for the post-resuscitation variables for the ibuprofen-treated and the vehicle control group of dogs. All values are presented as the mean \pm one standard error of the mean. The $P$-values are from Student's $t$-test. Sample size is given for each measurement. Missing values are due to death or mechanical failure.

\begin{tabular}{lcccccc}
\hline Variable name & $N$ & $\begin{array}{l}6 \text { h ibuprofen } \\
\text { infusion }\end{array}$ & $N$ & $\begin{array}{l}\text { Vehicle } \\
\text { control }\end{array}$ & $P$ \\
\hline $\begin{array}{c}\text { Heart rate } 6 \mathrm{~h} \\
\quad \text { (beats/min) }\end{array}$ & 8 & $127 \pm 17$ & 8 & $167 \pm 15$ & $\mathrm{NS}$ \\
$\begin{array}{c}\text { Heart rate } 24 \mathrm{~h} \\
\quad \text { (beats/min) }\end{array}$ & 7 & $144 \pm 13$ & 7 & $125 \pm 13$ & $\mathrm{NS}$ \\
$\begin{array}{c}\text { End expired } \mathrm{CO}_{2} \text { on } \\
\quad \text { ventilator }(\%)\end{array}$ & 8 & $4.5 \pm 0.2$ & 12 & $4.3 \pm 0.2$ & $\mathrm{NS}$ \\
$\begin{array}{c}\text { End expired } \mathrm{CO}_{2} \text { off } \\
\text { ventilator }(\%)\end{array}$ & 8 & $3.1 \pm 0.3$ & 12 & $3.4 \pm 0.2$ & $\mathrm{NS}$ \\
\hline
\end{tabular}

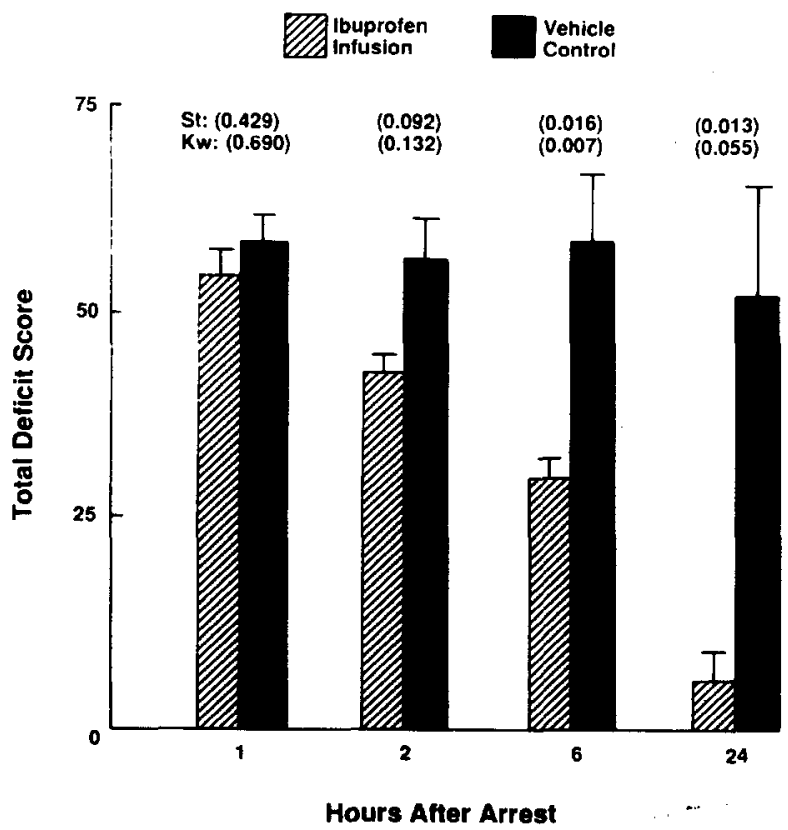

Fig. 3. Post-resuscitation Neurologic Deficit. Values are the mean \pm one standard error of the mean for the total neurologic score. St indicates $P$-values for Student's $t$-parametric tests, and $\mathrm{Kw}$ the $P$-values for Kruskel-Wallis non-parametric tests. 


\section{DISCUSSION}

\section{Methodological considerations}

In our hands, controlled cardiac arrest and resuscitation has been highly successful. Of 64 animals used for this and previous studies, 63 were successfully resuscitated; a failure rate of less than $1.6 \%$ (D'Alecy et al., 1986; Lundy et al., 1986). The drugs selected for use in this model were chosen to simulate a restricted and simplified advanced cardiac life support protocol. These restrictions were required to permit testing in a controlled experimental setting rather than optimizing resuscitation outcome by utilizing the full spectrum of interventions reported as effective in resuscitation. Although calcium chloride is no longer a part of the ACLS protocol, it was included in our treatment regimen because preliminary studies indicated it was needed to reduce electromechanical dissociation observed following prolonged arrests. The sodium bicarbonate dose was choosen to produce an arterial blood $\mathrm{pH}$ around 7.41. All dogs were fed prior to testing and all were given the same amount of dextrose to control for the potential damaging effects on resuscitation outcome of an elevated blood glucose (Myers and Yamaguchi, 1976; Longsteth et al., 1983b; D'Alecy et al., 1986; Lundy et al., 1986). The neurologic scoring used is our modification of schemes developed by Safar et al. (1976) and used by Todd et al. (1981 and 1982). To reduce bias, the scoring was done by individuals unaware of the treatment status of the animal. To increase consistency in the scoring, two or more investigators consulted written descriptions of each condition before a single score was agreed upon.

A potential criticism of this scoring method involved the inclusion of dead animals in a neurologic impairment scale. We feel justified in including the dead dogs in a neurologic impairment scale because their deaths were not due to ventricular fibrillation, hemorrhage or pneumothorax. The pattern of death was clearly suggestive of a primary cerebral event with maximum deficit in cranial and spinal nerves recorded prior to progressive depression of cardiopulmonary function. While it is true that the removal of these dead animals from the analysis eliminates the statistical separation of the groups it, at the same time, biases the data strongly in favor of the untreated group. All of the most severely damaged animals would be removed from the untreated group leaving only the least impaired animals of this group to compare with all the animals in the treatment group.

\section{Therapeutic potential of ibuprofen}

In addition to the clinical uses of ibuprofen as a potent anti-inflammatory agent, experiments have suggested that ibuprofen may have clinical applications in reducing myocardial infarct size (Jugdutt et al., 1980; Romson et al., 1982; Kirlin et al., 1982), improving the outcome following endotoxic shock (Jacobs et al., 1982), and improving survival in acute respiratory failure due to sepsis (Kopolovic et al., 1984). In this study we have shown that ibupro- 
fen may have an application in improving survival and neurologic recovery of resuscitated victims of cardiac arrest. Although ibuprofen may improve survival in the short term (12-24 h), it may not effect long term (weeks to months) neurologic impairment of survivors. The infusion of ibuprofen was only for $6 \mathrm{~h}$ and extending the time of infusion may be required to determine if long range effects are present.

Because the actions of ibuprofen are many and not yet fully explored, the proposed mechanisms of cerebral protection remain speculative. Ibuprofen is reported to limit granulocyte aggregation (McManus et al., 1980; Romson et al., 1982; Flynn et al., 1984). Normally, granulocytes aggregate in the presence of certain chemotactic agents such as $\mathrm{C5a}$ of the complement system (Jacob et al., 1980; Hammerschmidt et al., 1981). These chemotaxins are activated with the concurrent activation of the coagulation cascade, which follows cerebral ischemia (Anderson et al., 1974). These aggregations of granulocytes form leukoemboli, which can potentially occlude small $(60 \mu \mathrm{m})$ vessels (Hammerschmidt et al., 1981). It is known that with reperfusion following global ischemia, secondary changes occur in brain tissue that evolve into miliary microscopic infarcts (Safar, 1981). By preventing the granulocytes from aggregating, ibuprofen may limit leukoemboli formation and thus prevent miliary infarction of neural tissue.

Aggregated granulocytes could produce tissue damage through other mechanisms including: (1) the production of vasospasm-inducing leukotrienes which potentially restrict blood flow to the infarcted area (Michelassi et al., 1982); (2) the release of lysosomal enzymes which may cause additional cell damage by digesting critical cell membrane components (Flynn et al., 1984); and (3) the production of toxic oxygen free-radicals which may not only damage the membranes of neurons and glial cells surrounding an infarct (Demopolous et al., 1980; Del Maestro et al., 1980), but may also damage endothelial cells (Sacks et al., 1978) setting the stage for edema. Indeed, Wedmore and Williams (1981) have shown that granulocytes are required to produce edema at sites of inflammation. Although the early edema in the reperfused CNS is commonly thought to be due to the cytotoxic effects of ischemia (Klatzo, 1967; Hossmann, 1976), an inflammatory component which disrupts the vascular integrity may be a cause of vasogenic edema, which can occur late in the course in cerebral infarcts (Katzman, 1978).

Ibuprofen could limit the damaging effect of cardiac arrest and resuscitation by preventing granulocytes from aggregating, however, ibuprofen has also been shown to markedly reduce chronic cerebral vasospasm in dogs (Chyatte et al., 1983). This phenomenon is most likely a result of the ability of ibuprofen to inhibit the formation of vasoactive leukotrienes (Vanderhoek and Bailey, 1984). Interestingly, in animal models of cardiac arrest and resuscitation, Ames et al. (1968) and others (Gadzinski et al., 1982; White et al., 1983a, 1983b) have demonstrated a reduction in cerebral blood flow with reperfusion, sometimes to as low as $20 \%$ of normal. This "No-Reflow" 
phenomenon may be due in part to inflammatory mediators exhibiting a vascoactive effect. It is conceivable that by preventing the formation of these vasoactive compounds, ibuprofen may prevent this "No-Reflow" phenomenon and maintain cerebral blood flow thereby salvaging otherwise ischemic neural tissue.

Ibuprofen has been reported to decrease the release of lysozomal enzymes, inhibit the production of superoxide radicals, and prevent granulocyte mediated endothelial cytotoxicity (Flynn et al., 1984). All of these mechanisms have been invoked to describe the pathology of CNS ischemic disorders (Demopoulous et al., 1980; Del Maestro et al., 1980). Supporting the idea that these inflammatory mediators cause neural damage in the setting of cardiac arrest is the observation that early, irreversible histological damage will only become apparent if the neural tissue is allowed to be reperfused (Safar, 1982). In resuscitation from cardiac arrest, reperfusion could conceivably introduce the granulocytes and their inflammatory mediators into tissue already damaged by the transient ischemia of circulatory arrest. As the inflammatory mediators attempt to resolve damaged neurologic tissue, they would also cause additional damage to adjacent, healthy tissue. Because ibuprofen can prevent or inhibit these secondary inflammatory mechanisms, it is not unreasonable that in the setting of reperfusion following cardiac arrest, ibuprofen should have protective effects.

The descriptive nature of this study leaves open the question of how ibuprofen increases survival and decreases neurologic morbidity. Because there are limited pharmacologic resources available for intervening to lessen the brain damage associated with cardiac arrests, the preliminary data presented here are clearly encouraging and suggest that ibuprofen deserves further attention in this setting.

\section{ACKNOWLEDGEMENTS}

We thank Physio-Control, Redmond, WA, for the generous gift of the Lifepak-3 defibrillator/monitor. We thank Puritan Bennett Corporation, Westmont, IL, for the generous gift of a Compact "75" Anesthesia Machine and a Bennett BA-4 Anesthesia Ventilator. The Ibuprofen and the heparin were graciously supplied by the Upjohn Company, Kalamazoo, MI. We thank Karen M. Loyd for her technical assistance, Tamara Ball for the statistical data analysis, and Mary Harper for her editorial assistance.

\section{REFERENCES}

Ames, A., Wright, R.L., Kowada, M., Thurston, J.M. and Majno, G., (1968) Cerebral ischemia. II. The no-reflow phenomenon. Am. J. Pathol., 52, 437-453.

Anderson, J.M., Brown, J.K. and Cockburn, F. (1974) On the role of disseminated intravascular coagulation in the pathology of birth asphyxia. Dev. Med. Child Neurol., 16, $581-591$. 
Chyatte, D., Rusch, N. and Sundt, T.M. (1983) Prevention of chronic experimental cerebral vasospasm with ibuprofen and high-dose methylprednisolone. J. Neurosurg., 59, 925932.

D'Alecy, L.G., Lundy, E.F., Barton, K.J. and Zelenock, G.B. (1986) Dextrose containing intravenous fluid impairs outcome and increases death after 8 minutes of cardiac arrest and resuscitation in dogs. Surgery, 100, 505-511.

Del Maestro, R.F., Thaw, H.H., Bjork, J., Planker, M. and Afors, K.E. (1980) Free radicals as mediators of tissue injury. Acta Physiol. Scand., Suppl., 492, 43-57.

Demopoulos, H.B., Flamm, E.S., Pietronigro, D.D. and Seligman, M.L. (1980) The free radical pathology and the microcirculation in the major central nervous system disorders. Acta Physiol. Scand., Suppl., 492, 91-119.

Flynn, P.J., Becker, W.K., Vercellotti, G.M., Weisdorf, D.J., Craddock, P.R., Hammerschmidt, D.E., Lillehei, R.C. and Jacob, H.S. (1984) Ibuprofen inhibits granulocyte response to inflammatory mediators. Inflammation, 8, 33-44.

Gadzinski, D.S., White, B.C., Hoehner, P.J., Hoehner, T., Krome, C. and White, J.D. (1982) Canine cerebral cortical blood flow and vascular resistance post cardiac arrest. Ann. Emerg. Med., 11, 58-63.

Hammerschmidt, D.E., Harris, P.D., Wayland, H.J., Craddock, P.R. and Jacob, H.S. (1981) Complement-induced granulocyte aggregation in vivo. Am. J. Pathol., 102, $146-150$.

Hossmann, K.A. (1976) Development and resolution of ishemic brain swelling. In: Dynamics of Brain Edema, pp. 219-227. Editors: H.M. Pappius and W. Feidel. Springer-Verlag, New York.

Jacob, H.S., Craddock, P.R., Hammerschmidt, D.E. and Moldow, C.F. (1980) Complement-induced granulocyte aggregation, an unsuspected mechanism of disease. New Eng. J. Med., 302, 789-794.

Jacobs, E.R., Soulsby, M.E., Bone, R.C., Wilson, F.J. and Hiller, F.C. (1982) Ibuprofen in canine endotoxin shock. J. Clin. Invest., 70, 536-541.

Jugdutt, B.I., Hutchins, G.M., Bukley, B.H. and Beker, L.C. (1980) Salvage of ischemic myocardium by ibuprofen during infarction in the conscious dog. Am. J. Cardiol., 64, $74-82$.

Katzman, R. and Pappius, H.M. (1978) Brain Electrolytes and Fluid Metabolism. p. 375. Williams and Wilkins, Baltimore.

Kirlin, P.C., Romson, J.L., Pitt, B., Abrams, G.D., Schork, M.A. and Lucchesi, B.R. (1982) Ibuprofen-mediated infarct size reduction: effects on regional myocardial function in canine myocardial infarction. Am J. Cardiol., 50, 849-856.

Klatzo, I. (1967) Neurological aspects of brain edema. J. Neuropathol. Exp. Neurol., 26, $1-17$.

Kopolovic, R., Thrailkill, K.M., Martin, D.T., Ambrose, T., Vento, M., Carey, L.C. and Cloutier, C.T. (1984) Effects of ibuprofen on a porcine model of acute respiratory failure. J. Surg Res. 36, 300-305.

Longsteth, W.T., Jr., Inui, T.S., Cobb, L.A. and Copass, M.K. (1983) Neurologic recovery after out-of-hospital cardiac arrest. Ann. Intern. Med., 98, 588-592.

Longsteth, W.T., Jr., Diehr, P. and Inui, T.S. (1983) Prediction of awakening after out-ofhospital cardiac arrest. N. Engl. J. Med., 308, 1378-1382.

Lundy, E.F., Kuhn, J.E., Kwon, J.M., Zelenock, G.B. and D'Alecy, L.G. (1986) Infusion of $5 \%$ dextrose increases mortality and morbidity following six minutes of cardiac arrest in resuscitated dogs. J. Crit. Care, in press.

McManus, L., Pinckard, N., O'Rourke, R., Crawford, M. and Grover, F. (1980) Liffect of cobra venom factor (CVF) and ibuprofen on complement localization in ischemic baboon myocardium. Circulation, $62,13$.

Myers, R.E. and Yamaguchi, M. (1976) Effects of serum glucose concentration on brain response to circulatory arrest. J. Neuropathol. Exp. Neurol., 35, 301.

Michelassi, F., Landa, L., Hill, R.D., Lowenstein, E., Watkins, W.D., Petkau, A.J. and 
Zapol, W.M. (1982) Leukotriene D4, a potent coronary artery vasoconstrictor associated with impaired ventricular contraction. Science, 217, 841-843.

Romson, J.L., Hook, B.G., Rigot, V.H., Shork, M.A., Swanson, D.P. and Lucchessi, B.R. (1982) The effect of ibuprofen on accumulation of indium-III-labeled platelets and leukocytes in experimental myocardial infarction. Circulation, 66, 1002-1011.

Sacks, T.S., Moldow, C.F., Craddock, P.R., Bowers, T.K. and Jacobs, H.S. (1978) Oxygen radicals mediate endothelial cell damage by complement-stimulated granulocytes. J. Clin. Invest., 61, 1161-1167.

Safar, P. (1981) Resuscitation after brain ischemia. In: Brain Failure and Resuscitation, pp. 155-184. Editors: A. Grenvic and P. Safar, Churchill Livingstone, NY.

Safar, P. (1982) Cerebral resuscitation: current state of the art. Ann. Emerg. Med., 11(3), $162-165$.

Safar, P., Stezoski, W. and Nemoto, E.M. (1976) Amelioration of brain damage after 12 minutes cardiac arrest in dogs. Arch. Neurol., 33, 91-95.

Todd, M.M., Dunlop, B.J., Shapiro, H.M., Chadwick, H.C. and Powell, H.C. (1981) Ventricular fibrillation in the cat: A model for global cerebral ischemia. Stroke, 12(6), 808-815.

Todd, M.M., Chadwick, M.D., Shapiro, H.M., Dunlop, B.J., Marshall, L.F. and Dueck, R. (1982) The neurologic effects of thiopental therapy following experimental cardiac arrest in cats. Anesthesiology, 57(2), 76-86.

Vanderhoek, J.Y. and Bailey, J.M. (1984) Activation of a 16-lipoxygenase/leukotriene pathway in human polymorphonuclear leukocytes by the anti-inflammatory agent ibuprofen. J. Biol. Chem., 259, 6752-6756.

Wedmore, C.V. and Williams, T.J. (1981) Control of vascular permeability and polymorphonuclear leukocytes in inflammation. Nature, 289, 646-650.

White, B.C., Winegar, C.P., Henderson, O., Jackson, R.E., Krause, G., O'Hara, T., Goodin, T. and Vigor, D.N. (1983a) Prolonged hyperperfusion in the cerebral cortex following cardiac arrest and resuscitation in dogs. Ann. Emerg. Med., 12, 414-417.

White, B.C., Winegar, C.P., Jackson, R.E., Joyce, K.M., Vigor, D.N., Hoehner, T.J., Krause, G.S. and Wilson, R.F. (1983b) Cerebral cortical perfusion during and following resuscitation from cardiac arrest in dogs. Am. J. Emerg. Med., 1, 128-138. 